\title{
Update on the use of systemic biologic agents in the treatment of noninfectious uveitis
}

\author{
This article was published in the following Dove Press journal: \\ Biologics:Targets and Therapy \\ 15 February 2014 \\ Number of times this article has been viewed
}

\author{
Sirichai Pasadhika' \\ James T Rosenbaum² \\ 'Department of Ophthalmology, \\ Southern Arizona Veterans \\ Administration Health Care System, \\ Tucson, AZ, USA; ${ }^{2}$ Legacy Devers \\ Eye Institute, Portland, OR, USA
}

\begin{abstract}
Uveitis is one of the leading causes of blindness worldwide. Noninfectious uveitis may be associated with other systemic conditions, such as human leukocyte antigen B27-related spondyloarthropathies, inflammatory bowel disease, juvenile idiopathic arthritis, Behçet's disease, and sarcoidosis. Conventional therapy with corticosteroids and immunosuppressive agents (such as methotrexate, azathioprine, mycophenolate mofetil, and cyclosporine) may not be sufficient to control ocular inflammation or prevent non-ophthalmic complications in refractory patients. Off-label use of biologic response modifiers has been studied as primary and secondary therapeutic agents. They are very useful when conventional immunosuppressive therapy has failed or has been poorly tolerated, or to treat concomitant ophthalmic and systemic inflammation that might benefit from these medications. Biologic therapy, primarily infliximab, and adalimumab, have been shown to be rapidly effective for the treatment of various subtypes of refractory uveitis and retinal vasculitis, especially Behçet's disease-related eye conditions and the uveitis associated with juvenile idiopathic arthritis. Other agents such as golimumab, abatacept, canakinumab, gevokizumab, tocilizumab, and alemtuzumab may have great future promise for the treatment of uveitis. It has been shown that with proper monitoring, biologic therapy can significantly improve quality of life in patients with uveitis, particularly those with concurrent systemic symptoms. However, given high cost as well as the limited long-term safety data, we do not routinely recommend biologics as first-line therapy for noninfectious uveitis in most patients. These agents should be used with caution by experienced clinicians. The present work aims to provide a broad and updated review of the current and in-development systemic biologic agents for the treatment of noninfectious uveitis.
\end{abstract}

Keywords: biologics, monoclonal antibody, eye

\section{Introduction}

The term "uvea" comes from the Latin word for grape. The eye includes three layers. The middle layer, or uvea, encompasses the iris, ciliary body, and choroid. Inflammation of the uvea is termed uveitis, but it is usually diagnosed on the basis of inflammation in adjacent structures which include the anterior chamber, the vitreous humor, or the retina. Inflammation in the uvea can be due to infections, masquerades such as B-cell lymphoma, or immune-mediated diseases. The latter can be a systemic disease such as sarcoidosis or a disease confined to the eye such as sympathetic ophthalmia. Anatomic classification of uveitis is extremely useful, since the differential diagnosis is distinct for anterior, intermediate (involving the vitreous humor), posterior (involving the retina or choroid), and panuveitis. ${ }^{1}$
Correspondence: James T Rosenbaum Legacy Devers Eye Institute,

1040 NW 22nd Ave; Suite 200,

Portland, OR 97210 , USA

Tel +l 5034138203

Fax +I 5034136937

Email jtrosenb@lhs.org 
Uveitis is the third leading cause of blindness in the developed countries. The annual incidence is estimated between 17 and 52 per 100,000 persons, and the prevalence is 38-714 per 100,000 persons. $^{2}$ The incidence and prevalence vary among different geographic locations worldwide. Males and females are generally equally affected overall, but sex preponderance may be observed in some uveitis groups, such as male predominance in human leukocyte antigen (HLA)B27-associated uveitis and female preponderance in juvenile idiopathic arthritis (JIA)-related uveitis. Uveitis may occur at any age, but most commonly affects the working population aged between 20 and 59 years. Childhood uveitis is relatively less common, but may cause long-term severe visual loss. ${ }^{2}$ Therefore, the burden of this sight-threatening condition is very significant.

The most common symptoms of uveitis are decreased vision, eye pain, redness, light sensitivity, and floaters. The redness and eye pain are generally seen in eyes with acute anterior inflammation, but may not be prominent in chronically inflamed eyes or those in which the inflammation is confined only to the posterior segment. Uveitis is typically an immune-mediated condition, which involves chemical mediators resulting in vascular dilation (conjunctival injection), increased vascular permeability (aqueous flare), and chemotaxis of inflammatory cells into the eye (aqueous and vitreous cellular response). With variable chronicity and severity, uveitis may be complicated by cataract, glaucoma, band keratopathy, hyphema, vitreous hemorrhage, cystoid macular edema (CME), retinal detachment, retinal ischemia, optic atrophy, chronic eye pain, and blindness.

\section{Conventional therapy for uveitis}

Uveitis can be caused by infectious and noninfectious etiologies. Causative infectious origins may include bacteria, viruses, fungi, and parasites. The precise diagnosis is crucially important to establish an appropriate therapy. Specific antimicrobial treatment is typically required for infectious uveitis. In rare occasions, neoplastic diseases (eg, lymphoma) may masquerade as ocular inflammation, and an appropriate diagnosis is needed for proper management.

For noninfectious uveitis, excluding masquerade neoplasms, the control of inflammation is the key to treatment success. We generally use a stepladder approach; the treatment includes local corticosteroids, systemic corticosteroids, and systemic immune modulators, often sequentially starting with topical therapy. Noninfectious uveitides are often associated with other systemic conditions, such as HLAB27-related spondyloarthropathies, inflammatory bowel disease (IBD), JIA, Behçet's disease (BD), and sarcoidosis. The treatment of systemic symptoms may also improve ocular inflammation.

Topical corticosteroids are generally the initial treatment of choice for anterior uveitis, but they are not effective for the inflammation involving the posterior segment (behind the lens). Local corticosteroid therapy (eg, periocular and intravitreal corticosteroid injections, as well as corticosteroid implant devices) may be used in patients with posterior inflammation, especially those with monocular involvement. Topical and local corticosteroid therapies are notoriously known to potentially cause glaucoma and cataract. Systemic corticosteroids are often the mainstay of therapy for uveitis that involves the posterior segment, particularly when uveitis affects both eyes. Chronic use of moderate to high dose systemic corticosteroids can result in many serious side effects - impaired glucose tolerance, hypertension, fluid retention, osteoporosis, mental disturbance, impaired wound healing, gastrointestinal bleeding and perforation, thromboembolic disorders, weight gain, glaucoma, and cataract, for example. In cases that do not respond adequately to initial corticosteroid treatment or cases in which patients may develop serious corticosteroid-induced side effects, systemic corticosteroid-sparing immunomodulatory agents should be initiated.

Systemic immunomodulatory medications used for ocular inflammatory conditions include conventional immunosuppressive agents and biologic response modifiers. Examples of conventional systemic immunosuppressive agents used for uveitis and their common adverse effects are listed in Table 1. These agents include antimetabolites, inhibitors of T-cell signaling, and alkylating agents. ${ }^{3}$ Since they can cause potentially serious side effects, the patients must be monitored closely by experienced practitioners. With appropriate monitoring, immunosuppressive agents may effectively control ocular inflammation with acceptable safety profiles. ${ }^{4-8}$

\section{Systemic biologic therapy for noninfectious uveitis}

Biologic response modifiers, or so-called biologics, are the relatively new medications studied and used for the treatment of noninfectious uveitis and other ocular inflammatory diseases. We define a biologic as a medication which is manufactured by recombinant DNA (deoxyribonucleic acid) technology and which is designed to be effective based on a molecular understanding of disease pathogenesis. Biologics includes monoclonal antibodies, soluble receptors, 
Table I Examples of conventional systemic immunosuppressive agents that may be used for the treatment of noninfectious uveitis

\begin{tabular}{|c|c|c|c|c|}
\hline Medication & Mechanism of action & Dosage & Expected onset & Potential side effects \\
\hline \multicolumn{5}{|l|}{ Anti-metabolites } \\
\hline Methotrexate & $\begin{array}{l}\text { Inhibits dihydrofolate } \\
\text { reductase }\end{array}$ & $\begin{array}{l}7.5-25 \text { mg/week PO, } \\
\mathrm{SQ} \text {, or IM }\end{array}$ & $2-12$ weeks & $\begin{array}{l}\text { Gastrointestinal } \\
\text { disturbance, hepatotoxicity, } \\
\text { oral ulcers, fatigue, alopecia, } \\
\text { bone marrow suppression, } \\
\text { pneumonitis, fetal loss, and } \\
\text { infections }\end{array}$ \\
\hline Azathioprine & $\begin{array}{l}\text { Inhibits purine } \\
\text { metabolism }\end{array}$ & $\mathrm{I}-4 \mathrm{mg} / \mathrm{kg} /$ day PO & 4-12 weeks & $\begin{array}{l}\text { Gastrointestinal disturbance, } \\
\text { hepatotoxicity, fatigue, bone } \\
\text { marrow suppression, } \\
\text { hypersensitivity, and infections }\end{array}$ \\
\hline $\begin{array}{l}\text { Mycophenolate } \\
\text { mofetil }\end{array}$ & $\begin{array}{l}\text { Inhibits inosine } \\
\text { monophosphate } \\
\text { dehydrogenase }\end{array}$ & $\begin{array}{l}500-1,500 \mathrm{mg} P O \\
\text { twice daily }\end{array}$ & $2-12$ weeks & $\begin{array}{l}\text { Gastrointestinal disturbance, } \\
\text { bone marrow suppression, } \\
\text { and infections }\end{array}$ \\
\hline Leflunomide & $\begin{array}{l}\text { Inhibits dihydroorotate } \\
\text { dehydrogenase }\end{array}$ & $\begin{array}{l}100 \mathrm{mg} \text { PO daily } \\
(\times 3 \text { days), then } 20 \mathrm{mg} \text { PO } \\
\text { daily or every other day }\end{array}$ & 2 weeks & $\begin{array}{l}\text { Bone marrow suppression, } \\
\text { diarrhea, hypertension, fetal } \\
\text { loss, and infections }\end{array}$ \\
\hline \multicolumn{5}{|l|}{ T-cell inhibitors } \\
\hline Cyclosporine & Inhibits T-cell function & $\begin{array}{l}2.5-10 \mathrm{mg} / \mathrm{kg} / \text { day } \mathrm{PO} \\
\text { twice daily }\end{array}$ & $2-6$ weeks & $\begin{array}{l}\text { Nephrotoxicity, } \\
\text { hypertension, hirsutism, } \\
\text { gingival hyperplasia, and } \\
\text { infections }\end{array}$ \\
\hline Tacrolimus & Inhibits T-cell function & $0.15-0.30 \mathrm{mg} / \mathrm{kg} / \mathrm{day} \mathrm{PO}$ & $2-6$ weeks & $\begin{array}{l}\text { Nephrotoxicity, } \\
\text { hypertension, diabetes } \\
\text { mellitus, electrolyte } \\
\text { imbalance, and infections }\end{array}$ \\
\hline \multicolumn{5}{|l|}{ Alkylating agents } \\
\hline Chlorambucil & Alkylates nucleic acid & $0.1-0.2 \mathrm{mg} / \mathrm{kg} /$ day PO & $4-12$ weeks & $\begin{array}{l}\text { Bone marrow suppression, } \\
\text { infections, increased risk of } \\
\text { malignancy, and sterility }\end{array}$ \\
\hline Cyclophosphamide & Alkylates nucleic acid & $\mathrm{I}-3 \mathrm{mg} / \mathrm{kg} /$ day $\mathrm{PO}^{\mathrm{a}}$ & 2-8 weeks & $\begin{array}{l}\text { Bone marrow suppression, } \\
\text { infections, hemorrhagic } \\
\text { cystitis, increased risk of } \\
\text { malignancy, sterility, and } \\
\text { alopecia }\end{array}$ \\
\hline
\end{tabular}

Notes: aMay also be given IV every 3-4 weeks at an initial dose usually of $500 \mathrm{mg} / \mathrm{m}^{2}$ body surface area. Subsequent dosage is adjusted based on tolerance and nadir leukocyte counts. Adapted from Am J Ophthalmol, I30(4), Jabs DA, Rosenbaum JT, Foster CS, et al, Guidelines for the use of immunosuppressive drugs in patients with ocular inflammatory disorders: recommendations of an expert panel, 492-513, Copyright 2000, with permission from Elsevier. ${ }^{3}$

Abbreviations: IM, intramuscularly; IV, intravenously; PO, orally; SQ, subcutaneously.

cytokines themselves (such as interferons [IFNs]), and natural cytokine antagonists (such as anakinra). Biologic therapy can be an alternative in patients with inadequate response to or intolerance of conventional immunotherapy.

Biologics were developed and approved to treat systemic inflammatory diseases (eg, BD, JIA, ankylosing spondylitis [AS], psoriasis, psoriatic arthritis [PsA], ulcerative colitis [UC], Crohn's disease [CD], and rheumatoid arthritis [RA]) or to prevent organ transplant rejection. To date, none of the biologics discussed herein have been approved in the US for the treatment of uveitis, but they have been used off-label to treat uveitis or ocular inflammation. The clinical data have appeared primarily in case reports and series, and less frequently from clinical trials. The most commonly studied systemic biologics for uveitis to date are tumor necrosis factor (TNF)- $\alpha$ inhibitors, primarily infliximab, and adalimumab. Table 2 summarizes examples of biologics used in ophthalmology, dosage, route of administration, and their potential side effects.

One of the most successful biological approaches to disease is the inhibition of vascular endothelial growth factor (VEGF) within the eye since VEGF is strongly implicated in ocular neovascularization. VEGF is a contributor to $\mathrm{CME}$, and many investigators have reported their experience with the local injection of a VEGF inhibitor to treat CME secondary to uveitis. Since the rationale is to treat a complication of the uveitis rather than the uveitis itself, we have elected to omit a discussion of this important class of biologics from this review. 
Table 2 Characteristics, route of administration, dosage, and potential side effects for selected biologic agents

\begin{tabular}{|c|c|c|c|c|c|}
\hline Generic names & Trade names & Specific target & Route & Dosage & Potential side effects \\
\hline \multicolumn{6}{|l|}{ TNF inhibitors } \\
\hline Infliximab & Remicade & TNF- $\alpha$ & IV & $\begin{array}{l}3-5 \mathrm{mg} / \mathrm{kg} \text { loading at weeks } \\
0,2, \text { and } 6 \text {, then maintenance } \\
3-10 \mathrm{mg} / \mathrm{kg} \text { every } 4-8 \text { weeks; } \\
\text { maximal dose } 20 \mathrm{mg} / \mathrm{kg} \text { in children }\end{array}$ & $\begin{array}{l}\text { aSusceptibility to infections, } \\
\text { including: reactivation of } \\
\text { tuberculosis, histoplasmosis, } \\
\text { hepatitis B, and fungal infection; }\end{array}$ \\
\hline Adalimumab & Humira & TNF- $\alpha$ & SQ & $\begin{array}{l}40 \mathrm{mg} \text { every I- } 2 \text { weeks } \\
\text { (if bodyweight }<30 \mathrm{~kg} ; 20 \mathrm{mg} \\
\text { every } 2 \text { weeks); loading doses } \\
\text { of } 80-160 \mathrm{mg} \text { are recommended } \\
\text { for } \mathrm{CD} \text { and } \mathrm{PsO}\end{array}$ & $\begin{array}{l}\text { hypersensitivity reactions; } \\
\text { demyelinating disease; lupus- } \\
\text { like syndrome; malignancy; } \\
\text { thromboembolic events; } \\
\text { congestive heart failure }\end{array}$ \\
\hline Etanercept & Enbrel & TNF- $\alpha,-\beta$ & SQ & $\begin{array}{l}\text { Adults } 50 \mathrm{mg} \text { weekly (may be } \\
\text { given } 50 \mathrm{mg} \text { twice weekly for first } \\
3 \mathrm{months} \text { for PsO); children } \\
0.8 \mathrm{mg} / \mathrm{kg} / \text { week (max } 50 \mathrm{mg} / \text { week) }\end{array}$ & \\
\hline Golimumab & Simponi & TNF- $\alpha$ & SQ & $\begin{array}{l}50 \mathrm{mg} \text { SQ monthly; except } \\
\text { for UC } 200 \mathrm{mg} \text { at week } 0, \\
100 \mathrm{mg} \text { at week } 2 \text {, then } 100 \mathrm{mg} \\
\text { every } 4 \text { weeks }\end{array}$ & \\
\hline Certolizumab & Cimzia & TNF- $\alpha$ & SQ & $\begin{array}{l}400 \mathrm{mg} \mathrm{SQ} \text { at weeks } 0,2 \text {, and } 4 \text {, } \\
\text { then } 200 \mathrm{mg} \text { every } 2 \text { weeks or } \\
400 \mathrm{mg} \text { every } 4 \text { weeks }\end{array}$ & \\
\hline \multicolumn{6}{|c|}{ Lymphocyte inhibitors } \\
\hline Daclizumab & Zenapax & T-cells (IL-2R $\alpha)$ & IV, SQ & $\mathrm{I}-2 \mathrm{mg} / \mathrm{kg}$ every 2 or 4 weeks & $\begin{array}{l}\text { Hypersensitivity reactions, } \\
\text { headache, and gastrointestinal } \\
\text { disturbance }\end{array}$ \\
\hline Rituximab & Rituxan & B-cells (CD20) & IV & $\begin{array}{l}500 \text { or } 1,000 \mathrm{mg} \text { at week } 0 \text { and } 2 \text {; } \\
\text { may repeat at } 6-12 \text { months } \\
\text { thereafter (different regimen for } \\
\text { hematologic malignancies) }\end{array}$ & $\begin{array}{l}\text { Susceptibility to infections, } \\
\text { infusion reactions, } \\
\text { gastrointestinal disturbance, } \\
\text { cardiovascular events, muscle } \\
\text { spasm, and headache }\end{array}$ \\
\hline Abatacept & Orencia & T-cells (CTLA-4) & IV, SQ & $\begin{array}{l}\text { Adult RA } 500-1,000 \mathrm{mg} \text { IV } \\
\text { loading, then I } 25 \mathrm{mg} \text { SQ weekly; } \\
\text { JIA } 10 \mathrm{mg} / \mathrm{kg}, \max 1,000 \mathrm{mg} \\
\text { IV at weeks } 0,2 \text {, and } 4 \text {, then } \\
\text { every } 4 \text { weeks }\end{array}$ & $\begin{array}{l}\text { Susceptibility to infections, } \\
\text { allergic reactions, headache, } \\
\text { nausea, and malignancy }\end{array}$ \\
\hline Basiliximab & Simulect & $\begin{array}{l}\text { T-cells } \\
(\text { IL-2R } \alpha ; C D 25)\end{array}$ & IV & $\begin{array}{l}40 \mathrm{mg} \text { IV at weeks } 0,2,4,8 \text {, } \\
\text { and I } 2\end{array}$ & $\begin{array}{l}\text { Gastrointestinal disturbance, } \\
\text { headache, susceptibility to } \\
\text { infections, and hypersensitivity } \\
\text { reactions }\end{array}$ \\
\hline \multicolumn{6}{|c|}{ Specific receptor antagonists } \\
\hline Anakinra & Kineret & IL-I receptor & SQ & $\begin{array}{l}100 \mathrm{mg} \text { SQ daily; children, } \\
\text { starting I-2 } \mathrm{mg} / \mathrm{kg} \text { to max } \\
8 \mathrm{mg} / \mathrm{kg} \text { daily (dose adjustment } \\
\text { for renal insufficiency) }\end{array}$ & $\begin{array}{l}\text { Injection-site reaction, } \\
\text { infections, headache, } \\
\text { gastrointestinal disturbance, } \\
\text { and fever }\end{array}$ \\
\hline Canakinumab & llaris & IL-I $\beta$ & IV, SQ & $\begin{array}{l}\text { Systemic JIA: } 4 \mathrm{mg} / \mathrm{kg} \text { (max } \\
300 \mathrm{mg} \text { ) SQ every } 4 \text { weeks; } \\
\text { CAPS, } 2-3 \mathrm{mg} / \mathrm{kg} \text { SQ every } \\
8 \text { weeks (see text) }\end{array}$ & $\begin{array}{l}\text { Susceptibility to infections, } \\
\text { headache, nausea, and } \\
\text { abdominal pain }\end{array}$ \\
\hline Gevokizumab & (XOMA 052) & IL-I $\beta$ & IV, SQ & In experiment & $\begin{array}{l}\text { Susceptibility to infections and } \\
\text { hypersensitivity reactions }\end{array}$ \\
\hline Tocilizumab & Actemra & IL-6 receptor & IV & $\begin{array}{l}\text { Initial } 4 \mathrm{mg} / \mathrm{kg} \mathrm{IV} \mathrm{every} 4 \text { weeks, } \\
\text { then increase to } 8-12 \mathrm{mg} / \mathrm{kg} \\
\text { every } 2-4 \text { weeks }\end{array}$ & $\begin{array}{l}\text { Serious infections, } \\
\text { hypersensitivity reactions, and } \\
\text { gastrointestinal perforation }\end{array}$ \\
\hline Alemtuzumab & Campath & CD52 & IV & $\begin{array}{l}30 \mathrm{mg} \text { IV, } 3 \text { days per week for } \\
12 \text { weeks }\end{array}$ & $\begin{array}{l}\text { Cytopenias, infusion reactions, } \\
\text { infections, gastrointestinal } \\
\text { disturbance, and insomnia }\end{array}$ \\
\hline
\end{tabular}

(Continued) 
Table 2 (Continued)

\begin{tabular}{|c|c|c|c|c|c|}
\hline Generic names & Trade names & Specific target & Route & Dosage & Potential side effects \\
\hline Efalizumab & Raptiva & CDIIa & SQ & $\begin{array}{l}0.7 \mathrm{mg} / \mathrm{kg} \text { first dose, then I mg/kg } \\
\text { weekly (max } 200 \mathrm{mg} / \text { dose) }\end{array}$ & $\begin{array}{l}\text { Infections, progressive } \\
\text { multifocal leukoencephalopathy, } \\
\text { malignancy, arthritis, and } \\
\text { thrombocytopenia }\end{array}$ \\
\hline
\end{tabular}

\section{Interferons}

Interferon $\alpha-2 \mathrm{a}$

\author{
Roferon-A \\ Nonspecific
}

SQ
3-6 million units SQ daily, tapering
over 6 months
Injection-site reactions, flu-like symptoms, and bone marrow suppression

Notes: aListed side effects apply to all TNF inhibitors shown in this table. Copyright 2012.Adapted with permission from Retina Today. Pasadhika S, Suhler EB, Cunningham ET. Biologic therapy for posterior uveitis and panuveitis. Retina Today. 20I 2:74-79.49

Abbreviations: CAPS, cryopyrin-associated periodic syndromes; CD, Crohn's disease; IL, interleukin; IV, intravenously; JIA, juvenile idiopathic arthritis; PsO, plaque psoriasis; RA, rheumatoid arthritis; SQ, subcutaneously; TNF, tumor necrosis factor; UC, ulcerative colitis.

\section{TNF- $\alpha$ inhibitors}

Infliximab

Infliximab (Remicade ${ }^{\circledR}$, Janssen Biotech, Inc., Horsham, PA, USA) is a chimeric monoclonal antibody that binds both circulating and membrane-bound TNF- $\alpha$. It is approved for the treatment of RA, UC, CD, AS, PsA, and plaque psoriasis. Initial studies focused on the treatment of uveitis associated with BD and JIA. Infliximab has been described to be a rapid and very effective therapy for the treatment of $\mathrm{BD}$ related panuveitis, ${ }^{9-11}$ and retinal vasculitis. ${ }^{12}$ Sfikakis et al reported in a prospective study of 25 patients with BD-related uveitis that greater than $90 \%$ of patients demonstrated resolution of vitritis, CME, retinitis, and retinal vasculitis within 4 weeks after initiating infliximab therapy, and benefit often occurred in under 1 week. ${ }^{12}$ A prospective, observational study of patients with BD-related panuveitis comparing a single infliximab infusion $(5 \mathrm{mg} / \mathrm{kg})$, intravenous methylprednisolone ( $1 \mathrm{~g}$ /day for 3 days), and intravitreal triamcinolone acetonide injection $(4 \mathrm{mg})$, showed that those receiving infliximab achieved significantly faster resolution of retinal vasculitis, retinitis, and CME than those given systemic or intravitreal corticosteroid therapy. ${ }^{13}$ It was shown to be more effective than conventional immunotherapy for BD-related retinal vasculitis. ${ }^{14}$

Efficacy of infliximab for JIA uveitis also has been demonstrated in several retrospective studies, ${ }^{15-18}$ with the majority of patients experiencing rapid control of uveitis after the second infusion. ${ }^{15}$ Pediatric patients may require higher dose by weight or more frequent infusions compared with adults. ${ }^{19}$

Besides BD and JIA, infliximab has been reported to be effective for the treatment of uveitis associated with multiple diseases, including sarcoidosis, ${ }^{11,20-23}$ Vogt-KoyanagiHarada syndrome (VKH) ${ }^{20}{ }^{2 B D D},{ }^{20,24-26} \mathrm{AS},{ }^{27}$ psoriasis, ${ }^{27}$ and Takayasu disease. ${ }^{28}$ It may also be effective to treat birdshot chorioretinopathy (BSCR), ${ }^{11,20,29}$ recalcitrant uveitic CME, ${ }^{30}$ HLA-B27-related anterior uveitis, ${ }^{27,31,32}$ pars planitis, ${ }^{11,16}$ multifocal choroiditis, ${ }^{11}$ sympathetic ophthalmia, ${ }^{33}$ diffuse subretinal fibrosis, ${ }^{34}$ and idiopathic uveitis. ${ }^{11,20,35}$ Two-year results of a prospective trial for treatment of various uveitides showed that approximately three in four patients experienced initial benefit. Of the responders, there was a $60 \%$ retention rate of effectiveness in the first year and also $60 \%$ in the second year. ${ }^{36}$

Regarding sarcoidosis, TNF- $\alpha$ inhibitors may be effective in treating sarcoidosis-related systemic diseases and uveitis as mentioned. However, in patients receiving TNF- $\alpha$ inhibitors for treatment of other immune-mediated diseases, multiple case reports and series suggest that TNF- $\alpha$ inhibitors (infliximab, ${ }^{37-42}$ etanercept, ${ }^{37,40}$ and adalimumab ${ }^{40,41,43}$ ) may cause sarcoidosis-like conditions. Etiology remains unclear, but paradoxical sarcoidosis appearing during treatment is likely a class-effect of TNF- $\alpha$ inhibitors. ${ }^{44,45}$ TNF inhibitors analogously are effective for psoriasis, but they have also been reported to cause psoriasiform skin disease.

Infliximab has been reported to effectively treat serpiginous choroidopathy (SC) in two refractory cases; ${ }^{46,47}$ however, one patient died due to disseminated tuberculosis despite previously negative purified protein-derivative skin test. ${ }^{46}$ Mackensen et al described a high percentage (52\%) of QuantiFERON positivity in 21 serpiginous-like choroiditis patients, suggesting that tuberculosis in a European patient population may play an important etiologic role in some patients. ${ }^{48}$ Therefore, TNF- $\alpha$ inhibitors should be used with caution in patients with $\mathrm{SC} .49$

In our own open-label study on infliximab for various types of uveitis ${ }^{36}$ we encountered a very high rate of adverse reactions including 3 of 31 patients developing drug-induced lupus. Our study was too small to draw definitive conclusions, but we speculate that the combination of very high drug levels 
resulting from intravenous infusion and a minimal elevation in serum TNF in patients with just localized eye inflammation resulted in the inordinate number of adverse effects.

\section{Adalimumab}

Adalimumab (Humira ${ }^{\circledR}$, AbbVie Inc., North Chicago, IL, USA) is a fully human monoclonal antibody against TNF- $\alpha$. It is approved for the treatment of RA, UC, CD, PsA, plaque psoriasis, AS, and JIA. The route of administration is subcutaneous injection. Initial clinical studies have shown its potential for juvenile uveitis (mainly JIA), and more recent data have also demonstrated promising results in adults. A prospective, noncomparative, nonrandomized study in 14 children with recalcitrant uveitis (nine JIA and five idiopathic) described that improvement of anterior chamber inflammation was seen in $81 \%$ of affected eyes. ${ }^{50}$ A similar retrospective JIA study demonstrated control of uveitis and arthritis activity in more than $80 \%$ of cases, with median response time of 3 and 6 weeks for arthritis and uveitis, respectively. ${ }^{51}$ Adalimumab may be more effective when being used as the first biologic agent in JIA children. ${ }^{52}$ A retrospective study for JIA uveitis revealed that adalimumab effectively controlled inflammation in $35 \%$ of patients refractory to previous treatment with infliximab or etanercept. ${ }^{53}$

For BD-related uveitis, adalimumab could be an effective alternative for treatment in patients already well-controlled with infliximab wishing to switch from intravenous infusions to subcutaneous injections. ${ }^{54}$ Adalimumab could be very effective as the first biologic agent for this indication as well. ${ }^{55}$

A prospective open-label pilot study of adalimumab in 19 adults with various uveitides reported control of inflammation in $63 \%$ of patients and complete resolution of CME in $55 \%$ of eyes at 1 year of therapy. ${ }^{56} \mathrm{~A}$ more recent prospective trial of 31 patients (age range 20-66 years) with refractory uveitis from our group described $68 \%$ of subjects as clinical responders at 10 weeks, with $39 \%$ retention rate at 1 year. ${ }^{57}$ A prospective multicenter case series of 131 patients of any age (mean 27 years) also demonstrated that adalimumab therapy may significantly improve anterior chamber and vitreous inflammation with the ability to taper corticosteroids. For the patients with $\mathrm{CME}, 70 \%$ of eyes showed complete resolution of CME at 6 months. ${ }^{58}$

Adalimumab has been shown to reduce anterior uveitis flares in patients with AS. ${ }^{59}$ Successful adalimumab therapy has been reported for uveitis associated with sarcoidosis, VKH, CD, and BSCR, as well as idiopathic uveitis. ${ }^{57}$ Phase III studies on the efficacy and safety studies of adalimumab in the patients with active and inactive uveitis are in progress.

\section{Etanercept}

Etanercept (Enbrel ${ }^{\circledR}$, Immunex Corporation, Thousand Oaks, CA, USA) is a fusion protein of a human Fc molecule and two p75 TNF receptors which binds free TNF- $\alpha$ and $-\beta$. It is approved for the treatment of RA, polyarticular JIA, AS, PsA, and plaque psoriasis. Favorable outcomes of etanercept therapy for uveitis have been previously reported. ${ }^{60}$ A prospective, open-label, multicenter study with median follow-up of 13 months showed that patients with JIA may initially respond to etanercept, but only approximately half of responders had sustained improvement at 1 year. ${ }^{61}$ Interestingly, etanercept failed to show significant difference in control of anterior chamber inflammation, compared with placebo, in a randomized trial. ${ }^{62}$ Furthermore, it was not superior to placebo in preventing uveitic relapses in previously controlled patients attempting to taper methotrexate in another randomized study. ${ }^{63}$ Based on the existing uncontrolled data, infliximab and adalimumab generally are believed to be more effective than etanercept for the treatment of ocular inflammation. ${ }^{64}$ However, there are no prospective head-to-head studies of the effectiveness or safety among the TNF- $\alpha$ inhibitors.

Just as TNF inhibitors may paradoxically trigger psoriasis or sarcoidosis, uveitis has been reported as a consequence of anti-TNF therapy. ${ }^{65,66}$ Etanercept appears to be more likely than infliximab or adalimumab to cause this very rare adverse effect. ${ }^{67}$

\section{Golimumab}

Golimumab (Simponi ${ }^{\circledR}$, Janssen Biotech, Inc) is approved for the treatment of moderate to severe active RA, PsA, AS, and UC. The recommended dose for RA, PsA, and AS is $50 \mathrm{mg}$ by subcutaneous injection every month, with a higher dose for UC (see Table 2). Several case reports and series demonstrated successful control of recalcitrant uveitis associated with JIA, ${ }^{68-70} \mathrm{BD},{ }^{71}$ idiopathic retinal vasculitis, ${ }^{68}$ spondyloarthropathies, ${ }^{72}$ and HLA-B27 positivity. ${ }^{70}$

The largest data to date are on the use for JIA-related uveitis in ten patients from three series. ${ }^{68-70}$ Cordero-Coma et al reported a case with history of infliximab intolerance, and adalimumab failed to control arthritis. Ocular and joint inflammation were successfully controlled after switching to golimumab with concurrent use of methotrexate. ${ }^{68}$ Similar results were observed in other series. ${ }^{69,70}$ Miserocchi et al reported that improvement of ocular inflammation may be 
observed as soon as 2 weeks after initiation of golimumab. ${ }^{70}$ Like other TNF- $\alpha$ inhibitors, initial response can be prompt; ocular and articular inflammation may subsequently become resistant to golimumab after several months of successful treatment. ${ }^{69}$ In some occasions, more frequent injections may be required to control uveitis, as seen in a 15-year-old girl whose uveitis flared prior to 4 weeks, and her uveitis was successfully controlled with 3 -week injection intervals. ${ }^{69}$ Golimumab may enable corticosteroids and conventional immunosuppression tapering. ${ }^{68-70}$

Faez et al showed that golimumab may be effective for uveitis associated with spondyloarthropathies (AS and PsA). In this series, a 31-year-old male with AS and bilateral anterior uveitis was satisfactorily treated with at least 30 months of follow-up. Golimumab may further assist the control of systemic conditions in those with inactive uveitis, as reported in a 7-year-old girl with uncontrolled joint inflammation (PsA), while her panuveitis was quiescent under mycophenolate mofetil therapy. ${ }^{72}$

Mesquida et al reported successful outcomes in a 28-yearold male with BD-related panuveitis, occlusive retinal vasculitis, and CME. The conditions were inadequately controlled with cyclosporine, infliximab, and prednisone. Golimumab therapy resulted in complete resolution of vitritis and macular edema 5 weeks after switching from infliximab to golimumab. Uveitis remained quiescent after cyclosporine and prednisone tapering up to 6 months of follow-up. ${ }^{71}$ A similar observation was reported in a 28 -year-old man with idiopathic retinal vasculitis from another series. ${ }^{68}$

As noted above, golimumab seems to be a promising treatment option for various uveitis subtypes based on limited data available to date. All of these cases underwent golimumab therapy after either inadequate response to or intolerance of other biologics, mainly other TNF- $\alpha$ inhibitors. As a relatively new medication, golimumab was used as a primary biologic agent in none of the above reported cases. An open-label, Phase IV study, investigating the incidence of uveitis attacks in participants with AS before and after treatment with golimumab is underway.

\section{Certolizumab}

Certolizumab (Cimzia ${ }^{\circledR}$, UCB, Inc., Smyrna, GA, USA) differs from other anti-TNF- $\alpha$ monoclonal antibodies in that it contains the Fab fragment which is bound to polyethylene glycol instead of the Fc fragment for increasing the half-life. It is approved for the treatment of moderate to severe RA, PsA, and CD. A single case report demonstrated its efficacy for the treatment of recalcitrant RA and scleritis in a patient who was intolerant to infliximab and rituximab therapy. ${ }^{73}$ To date, there are no reports on its use for uveitis or other ophthalmic conditions.

\section{Lymphocyte inhibitors}

\section{Daclizumab (T-lymphocyte inhibitor)}

Daclizumab (Zenapax ${ }^{\circledR}$, Genentech, Inc., South San Francisco, CA, USA) is a monoclonal antibody which binds the interleukin (IL)- $2 \alpha$ receptor subunit expressed by most T- and B-lymphocytes and natural killer cells. It was used for the prophylaxis of organ transplant rejection. A Phase I/II open-label study of intravenous daclizumab $(1 \mathrm{mg} / \mathrm{kg}$ every 4 weeks) for the treatment of noninfectious intermediate and posterior uveitis demonstrated improvement of inflammation and visual acuity at 1 year in $80 \%$ of patients, ${ }^{74}$ which was sustained after 4 years of therapy. ${ }^{75}$ Increased uveitic flares were observed with reduction to 6-weekly infusions compared with 2-4-weekly infusions. Some patients were transitioned to subcutaneous daclizumab therapy after 4 years of intravenous infusions, with most patients maintaining good response. ${ }^{75}$ Two-third of patients who received subcutaneous daclizumab injections ( $2 \mathrm{mg} / \mathrm{kg}$, followed by $1 \mathrm{mg} / \mathrm{kg}$ maintenance every other week) in a subsequent study achieved at least $50 \%$ reduction of concurrent immunosuppression, with retained baseline visual acuity and control of uveitis. ${ }^{76}$

For some specific uveitis groups, intravenous daclizumab $(1 \mathrm{mg} / \mathrm{kg})$ at 2 -week intervals has been shown to be effective for refractory BSCR in a retrospective study, with seven of eight patients achieving complete resolution of vitreous inflammation and stabilization or improvement of visual acuity in both eyes. Resolution of retinal vasculitis on fluorescein angiography was observed in $75 \%$ of the subjects. ${ }^{77}$ Higher intravenous doses were also used for JIA uveitis, BSCR, idiopathic panuveitis, intermediate uveitis, and VKH. ${ }^{78,79}$ However, daclizumab failed to demonstrate effectiveness in BD-associated uveitis in a randomized trial, with the placebo group experiencing greater reduction in immunosuppressive agents. ${ }^{80}$

Despite promising results in managing uveitis, daclizumab was discontinued by the manufacturer in 2009 due to diminishing market demand with available alternative treatments, and presumably not due to its safety concerns.

\section{Rituximab (B-lymphocyte inhibitor)}

Rituximab (Rituxan ${ }^{\circledR}$, Genentech, Inc.) is a CD20-directed cytolytic antibody indicated for the treatment of non-Hodgkin's lymphoma, chronic lymphocytic leukemia, RA, granulomatosis with polyangiitis (formerly Wegener's granulomatosis), 
and microscopic polyangiitis. It is given by intravenous infusions in various doses depending on the diagnosis. Case reports and series demonstrated benefits for scleritis and orbital inflammatory diseases. ${ }^{81-83}$ Results from prospective randomized clinical trials for the treatment of refractory noninfectious scleritis (in review) and orbital inflammation (in press) show that rituximab therapy is effective to control inflammation in the majority of participants.

Some evidence suggests that rituximab may be effective for the treatment of BD-related conditions, in spite of the fact that it is conceptualized predominantly as a T-celldriven disease. Sadreddini et al reported that one course of two rituximab infusions (1,000 $\mathrm{mg}, 2$-week interval) was effective to control BD-related uveitis and retinal vasculitis, and control of inflammation was sustained at 18 months of follow-up. ${ }^{84}$ A subsequent prospective trial was conducted in 20 patients with refractory, active BD-related uveitis, retinal vasculitis, and edema. The subjects were randomized into two groups: the first received two doses of $1,000 \mathrm{mg}$ rituximab (15-day interval), $15 \mathrm{mg}$ methotrexate, and prednisone $0.5 \mathrm{mg} / \mathrm{kg} / \mathrm{day}$; the second group was given pulse cyclophosphamide (1,000 mg/month), azathioprine (2-3 $\mathrm{mg} / \mathrm{kg} /$ day), and prednisone $(0.5 \mathrm{mg} / \mathrm{kg} /$ day $)$. The results showed that the rituximab group had more substantial improvement of the Total Adjusted Disease Activity Index, while ocular inflammation was significantly improved in both groups. ${ }^{85}$

Experience in treating refractory JIA uveitis was demonstrated in two retrospective case series (eight and ten patients). ${ }^{86,87}$ After two infusions at a 2 -week interval, uveitis inactivity was typically observed 4-5 months after the first infusions, ${ }^{86}$ but approximately half of the patients may need a third infusion at 6-12 months due to uveitic flare. ${ }^{86,87}$ In the patients with oligoarthritis, their uveitis tended to respond to rituximab treatment better than those with polyarthritis, but the study population was too small to draw a definitive conclusion. $^{87}$

Rituximab may also be effective for the treatment of $\mathrm{BSCR}^{88}$ and essential cryoglobulinemia-associated uveitis. $^{89}$

\section{Abatacept (T-lymphocyte inhibitor)}

Abatacept (Orencia ${ }^{\circledR}$, Bristol-Myers Squibb Company, New York, NY, USA) is a soluble fusion protein composed of a fragment of human immunoglobulin and the ligandbinding domain of cytotoxic T-lymphocyte-associated antigen-4. The fusion protein binds to an antigen presenting cell and blocks the activity of what is called an accessory molecule that activates the T-cell. Abatacept is approved for the treatment of RA and JIA. It is given by monthly intravenous infusions after initial loading at 0,2 , and 4 weeks in children with JIA, but may be used as weekly subcutaneous injections after a single intravenous loading in adults with RA. Several reports demonstrated its efficacy to control or improve refractory JIA-uveitis in children and young adults (range, 8-23 years old) with intravenous infusions. ${ }^{90-93}$ The patients were previously recalcitrant or intolerant to two or more biologics (eg, TNF- $\alpha$ inhibitors, daclizumab, and rituximab). To date, Zulian et al reported the largest series of seven patients. The results showed that uveitis was improved in all patients, but only one patient had complete remission over the 7-11-month follow-up period. One patient discontinued treatment due to oral mycosis and arthritic flare. ${ }^{91}$ A subsequent report with longer follow-up (19-23 months) showed that, of the six patients who maintained therapy, five remained in good control, but one had both arthritic and uveitic flares at 12 months after starting treatment. ${ }^{92}$ A single report and two small case series showed that abatacept may result in complete remission of uveitis and/or complete resolution of macular edema after several months of treatment. ${ }^{90,92,93}$ In patients with well-controlled uveitis under abatacept, the infusion intervals may be successfully increased to every 6-7 weeks without flares of ocular or articular conditions. ${ }^{92}$ Abatacept may adequately control uveitis, but not arthritis in some occasions. ${ }^{93} \mathrm{~A}$ randomized, Phase II controlled trial of abatacept for the treatment of noninfectious uveitis from our group is in progress. Preliminary results showed that abatacept was effective, at least partially, to control refractory uveitis in the first three patients enrolled thus far. ${ }^{94}$

\section{Basiliximab (T-lymphocyte inhibitor)}

Basiliximab (Simulect ${ }^{\circledR}$, Novartis Pharmaceuticals Corporation, East Hanover, NJ, USA) is a chimeric monoclonal

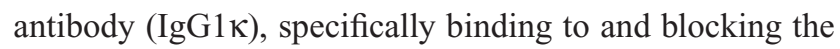
IL-2 receptor $\alpha$-chain (IL-2R $\alpha$, also known as CD25 antigen) on the surface of activated T-lymphocytes. It is approved for the prophylaxis of acute renal transplant rejection. A randomized controlled pilot study of its use for high-risk penetrating keratoplasty showed that it has inferior efficacy in preventing graft reactions compared with cyclosporine. ${ }^{95} \mathrm{~A}$ clinical trial on the safety and efficacy of basiliximab as maintenance therapy for stable noninfectious uveitis was started in March 2008, but was terminated in November 2008, pending further studies in non-ophthalmic indications. There are no reports on the use for uveitis at present. 


\section{Specific receptor antagonists}

Anakinra

Anakinra (Kineret ${ }^{\circledR}$, Swedish Orphan Biovitrum AB [publ], Stockholm, Sweden) is a competitive IL-1 receptor antagonist which prevents the activation of IL-1-mediated immune response. It is approved for the treatment of RA and cryopyrin-associated periodic syndromes. The recommended dose for RA is $100 \mathrm{mg}$ daily by subcutaneous injection, and dose adjustment is needed for renal insufficiency. An animal study showed that it may suppress experimental immune-mediated uveitis in mice. ${ }^{96}$ Clinical data on its use for uveitis are limited to a single case report of successful treatment in a 6-year-old boy with refractory chronic infantile neurological cutaneous articular syndrome-associated bilateral panuveitis. In this case, anakinra ( $1 \mathrm{mg} / \mathrm{kg} /$ day $)$ enabled withdrawal of oral prednisone with remission of ocular inflammation. ${ }^{97}$ A clinical trial of anakinra for the treatment of BD is now recruiting participants.

\section{Canakinumab}

Canakinumab (Ilaris ${ }^{\circledR}$, Novartis Pharmaceuticals Corporation) is an IL-1 $\beta$ blocker indicated for systemic JIA and cryopyrin-associated periodic syndromes in adults and children 4 years of age or older. It is generally administered by subcutaneous injection every $4-8$ weeks, but can also be given intravenously. Ugurlu et al described a case of a 16-year-old female with severe bilateral panuveitis with hypopyon and retinal vasculitis associated with BD. The patient was intolerant to IFN therapy and refractory to conventional immunosuppressive and several biologic agents, including infliximab, adalimumab, and anakinra. The inflammation resolved with improved visual acuity, which was sustained for at least 8 weeks after a single infusion of $150 \mathrm{mg}$ canakinumab. However, there were no long-term outcomes presented..$^{98}$

Simonini et al reported efficacy of canakinumab for the treatment of intractable uveitis with macular edema and retinal detachment in a 16-year-old male with a diagnosis of Blau syndrome (onset at 4 years of age), a nucleotide-binding oligomerization domain-containing protein 2-associated pediatric granulomatous uveitis and arthritis. The patient had inadequate response to conventional immunosuppression and biologics, including infliximab, adalimumab, and abatacept. Canakinumab was given $2 \mathrm{mg} / \mathrm{kg} / \mathrm{month}$ with concurrent use of oral methotrexate and low-dose prednisone, and led to rapid quiescence of uveitis, which was sustained for at least 6 months of therapy. The treatment also resulted in normalization of most gene expression profiles that overlapped with the transcriptional signature of patients with systemic JIA. The authors postulated that canakinumab may be particularly useful for uveitis associated with this rare syndrome..$^{99}$

\section{Gevokizumab}

Gevokizumab (XOMA 052, XOMA Corporation, Berkeley, CA, USA) is a humanized monoclonal antibody that binds to IL-1 $\beta$. Phase III multicenter clinical trials for active noninfectious uveitis (EYEGUARD ${ }^{\mathrm{TM}}-\mathrm{A}$ ), controlled noninfectious uveitis (EYEGUARD ${ }^{\text {TM}}-\mathrm{C}$ ), and BD-associated uveitis (EYEGUARD ${ }^{\text {TM}}-\mathrm{B}$ ) are underway. The medication is also currently being studied for scleritis, moderate to severe inflammatory acne, diabetes, and erosive osteoarthritis of the hand.

A 98-day pilot study that enrolled seven patients with active BD-related uveitis and retinal vasculitis resistant to azathioprine and/or cyclosporine showed that a single infusion of gevokizumab $0.3 \mathrm{mg} / \mathrm{kg}$ resulted in rapid improvement of uveitis in 1-4 days with complete resolution of retinal vasculitis in all patients (median 14 days), and sustained response was observed for 21-97 days (median 49 days). No treatment-related side effects were observed in this short-term study. ${ }^{100}$

\section{Tocilizumab}

Tocilizumab (Actemra ${ }^{\circledR}$, Genentech, Inc.) is an anti-IL-6 receptor monoclonal antibody. It is approved for the treatment of RA, as well as polyarticular and systemic JIA. Recommended doses vary from 4 to $12 \mathrm{mg} / \mathrm{kg}$ intravenous infusion every 2-4 weeks, depending on underlying conditions and clinical response.

Tappeiner et al reported a successful suppression of uveitis with tocilizumab in two out of three patients with JIA-related uveitis refractory to adalimumab, etanercept, and/or abatacept. Uveitis inactivity was observed at 1 month and maintained at least 6 and 12 months of follow-up in the two patients. One patient had improvement of arthritis, but uveitis remained active. ${ }^{101}$ Described by Hirano et al, a 47-year-old woman with severe BD-related posterior uveitis resistant to immunosuppression and infliximab therapy experienced complete remission of posterior uveitis, genital ulcers, and erythema nodosum after switching to tocilizumab monotherapy. ${ }^{102}$ Not only controlling uveitis, tocilizumab infusions may also lead to regression of retinal exudation and macular edema associated with retinal vasoproliferative tumor, as reported in a 29 -year-old female with chronic JIA-associated uveitis. ${ }^{103}$ 
The use of tocilizumab for a rare multicentric Castleman disease, relating an overproduction of IL-6 due to plasma cell hyperplasia, was demonstrated by Oshitari et al to treat a 58-year-old man with refractory uveitis, chronic fever, fatigue, and pulmonary infiltration. Resolution of uveitis and perivascular leakage on fluorescein angiogram was achieved at 3 months after treatment. ${ }^{104}$

CME is one of leading causes of decreased vision in patients with uveitis. Interestingly, one retrospective case series studied eight eyes of five patients with mildly active uveitis (three with BSCR, one with JIA, and one with idiopathic uveitis) and severe long-standing CME (mean 13.4 years of CME evolution) recalcitrant to immunosuppression, local corticosteroid injection, and at least one TNF- $\alpha$ inhibitor. Tocilizumab infusions led to significant improvement of macular thickness on optical coherence tomography (mean, from $602 \pm 236$ to $295 \pm 95$ microns, before and 6 months after treatment, respectively). Improvement in visual acuity was observed in $75 \%$ of eyes. ${ }^{105}$ Given these promising results, clinical trials on its use for uveitis and CME are warranted. A Phase I/II clinical trial on tocilizumab therapy for JIA-related uveitis, and a study on its safety, tolerability, and bioactivity for noninfectious intermediate, posterior, and panuveitis, are in progress.

Of note, tocilizumab was given at $8 \mathrm{mg} / \mathrm{kg}$ intravenously every 4 weeks for all aforementioned cases, ${ }^{101-103,105}$ except the patient with Castleman disease who received the same dose at 2-week intervals. ${ }^{104}$ Although tocilizumab therapy may improve systemic rheumatic symptoms, possible paradoxical inflammatory responses have been proposed, as observed in a 41-year-old male with HLA-B27-positive AS who developed his first episode of uveitis and a 65 -year-old male with RA whose peripheral ulcerative keratitis occurred for the first time, after 2 and 11 months of tocilizumab therapy, respectively. ${ }^{106}$

\section{Alemtuzumab}

Alemtuzumab (Campath ${ }^{\circledR}$, Genzyme Corporation, Cambridge, MA, USA) is a CD52-directed cytolytic antibody indicated as a single agent for the treatment of B-cell chronic lymphocytic leukemia. It has also demonstrated benefit in other conditions such as RA and multiple sclerosis. ${ }^{107,108}$ In 1995 , Isaacs et al described a case of a 36-year-old man who presented with severe panuveitis with choroiditis and retinal vasculitis resistant to immunosuppressive agents, including cyclophosphamide and intravenous immunoglobulin. The patient had significant systemic symptoms, presumably from chronic corticosteroid therapy. He was given intravenous alemtuzumab $12 \mathrm{mg}$ daily for 5 days (at 45 years of age) with brief improvement of ocular inflammation. However, the patient subsequently died with myocardial infarction. ${ }^{109}$ In 2000, Dick et al reported a series of ten patients with various ocular inflammatory diseases treated with intravenous alemtuzumab $10-12 \mathrm{mg}$ daily for 5 days. Of the ten patients, six had uveitis (four with retinal vasculitis, one with BDrelated uveitis, and one with sympathetic ophthalmia). The first five patients had clinical improvement, but the latter with sympathetic ophthalmia had stable inflammation without deterioration. ${ }^{110}$

Indirect data on uveitis were also reported in a study of 18 patients with active BD treated with escalating doses of intravenous alemtuzumab at 4, 10, 40, 40, and $40 \mathrm{mg}$ daily for 5 consecutive days (total $134 \mathrm{mg}$ ). Of the 18 patients, 12 had ocular manifestations, but only four had active uveitis at the time of alemtuzumab therapy. Of the four, two had complete remission and two had partial improvement at 6 months after treatment. ${ }^{111}$

\section{Efalizumab}

Efalizumab (Raptiva ${ }^{\circledR}$, Genentech, Inc.) is an anti-CD11a antibody. One case report showed that 37 weekly subcutaneous injections of efalizumab effectively treated recalcitrant uveitic CME, and the effect was durable 6 months after discontinuation of treatment. ${ }^{112}$ A subsequent prospective noncomparative Phase I/II trial using 16 weekly subcutaneous injections in six patients also showed its efficacy in improving uveitic CME. ${ }^{113}$ However, efalizumab was withdrawn from the market due to increasing risk of progressive multifocal leukoencephalopathy. ${ }^{114}$

\section{IFNs}

IFN- $\alpha$ and $-\beta$ are naturally occurring cytokines affecting the immune system. IFN- $\alpha 2 \mathrm{a},-\alpha 2 \mathrm{~b}$, and $-\beta 1 \mathrm{a}$ have been reported to be useful in the treatment of refractory ocular inflammation and associated CME, particularly in patients with $\mathrm{BD}^{115}$ and multiple sclerosis. ${ }^{116} \mathrm{~A}$ review article by Kötter et al analyzing 36 studies (between 1986 and 2002) on the use of IFN therapy for BD showed that 182 out of 338 patients (54\%) were given IFN due to acute uveitis. Approximately $94 \%$ of the patients achieved partial or complete resolution of uveitis, generally within $2-4$ weeks. ${ }^{117}$ Both IFN- $\alpha 2 a^{118}$ and $-\beta 1 a^{116}$ have been shown to effectively treat uveitic CME in approximately $70 \%$ of patients. However, relapse is frequently seen after discontinuation of IFN treatment. To date, only IFN- $\alpha$ has been shown to control ocular inflammation with sustained remission even after discontinuation 
of therapy. ${ }^{119}$ IFN therapy may cause potentially serious complications. Multiple cases of possible IFN-induced sarcoidosis with ${ }^{120}$ or without ${ }^{121}$ uveitis have been reported. Therefore, we generally do not recommend IFN therapy for sarcoid-related uveitis.

\section{Treatment of uveitis and its impact on quality of life (QOL)}

It has been estimated that uveitis accounts for approximately $10 \%$ of visual disability in Western countries, and up to $35 \%$ of patients with uveitis have been reported to have significant visual impairment or legal blindness. ${ }^{122,123}$ However, visual acuity itself may not always reflect the quality of vision, as many patients may experience various degrees of decreased visual field, decreased contrast sensitivity, alteration of depth and color perception, increased light sensitivity, glares, and floaters. Compared with healthy subjects, patients with uveitis have significantly worse visual functioning and overall health status, leading to severely impaired QOL. ${ }^{124}$ Furthermore, patients with severe ocular inflammation commonly require systemic corticosteroid or immunosuppressive therapy, which may impact health-related QOL (HR-QOL) due to adverse drug reactions. As mentioned, uveitis more commonly affects the working population, whose onsets of symptoms typically occur earlier in life than those with age-related eye diseases such as cataracts, glaucoma, and age-related macular degeneration. ${ }^{2}$ Therefore, uveitis therapy is cumulatively associated with high social and economic burdens. ${ }^{125}$ The National Eye Institute Visual Function Questionnaire (NEI VFQ), and the simplified version, NEI VFQ-25, were developed to measure vision-specific QOL (VS-QOL) for visually impaired individuals. Schiffman et al applied the NEI VFQ-25 with the Medical Outcomes Study Short-Form 36 to measure HR-QOL in patients with uveitis. ${ }^{124}$ We recommend that both tools be used to assess VS-QOL and HR-QOL in patients with uveitis. ${ }^{126}$

When focusing mainly on biologic therapy for systemic conditions, the data from the JuMBO (Juvenile Arthritis MTX/Biologics Long-Term Observation), a prospective cohort study following adult JIA patients formerly included in the national JIA biologic registry, showed that etanercept therapy offered improved long-term outcomes and HR-QOL of patients with severe JIA. ${ }^{127}$

The influence of uveitis treatment may be even more prominent when the patients suffer from both vision-threatening and systemic manifestations. BD is one of the best examples that biologic therapy may have significant impact to improve QOL as simultaneously improving both systemic and visual conditions. Sakai et al studied 20 patients with BD and recurrent uveitis attack, and found that infliximab therapy significantly improved VS-QOL and HR-QOL in patients with BD-related uveitis. ${ }^{128} \mathrm{~A}$ similar observation was observed with the use of tocilizumab for the same condition, by improving physical health (physical functioning, role physical, body pain, and general health perceptions) and mental health (vitality, social functioning, and role emotion). ${ }^{102}$

Biologic therapy is generally more costly compared with conventional immunosuppression. However, an example of biologics, abatacept, is believed to be cost-effective for the treatment of RA. ${ }^{129}$ The cost-effectiveness of the use of biologics for uveitis is yet to be confirmed.

\section{Future targets, limitations, and unknowns}

Although biologics have great potential in the treatment of uveitis, the application of biologic therapy has been hampered by several factors. First, uveitis is relatively rare compared with immune-mediated diseases such as RA or psoriasis. As a consequence, recruitment is often promoted by combining various etiologies of uveitis together. However, it is likely that differences in pathogenesis also mean differences in therapeutic response. Just as gout and RA may respond to different treatments, a drug which is efficacious for BD might not succeed in treating VKH. Second, different forms of uveitis require different endpoints. Vitreous haze might be important in pars planitis, but it is not a valuable endpoint in BSCR. Trials which lump different subtypes of uveitis together are hampered by the use of endpoints that might not fit all diagnoses equally.

Many additional targets have been identified for biologic therapy in diseases other than uveitis. Examples of targets to inhibit include a molecule common to IL-12 and IL-23, IL-23 alone, IL-17 or its receptor, IL-15, IFN- $\alpha$, and a variety of adhesion molecules. With the exception of the antibody to the peptide chain shared by IL-12 and IL-23 (ustekinumab) and the antibody to alpha-4 integrin (natalizumab), all of these molecules are in various stages of testing, and their potential use in treating uveitis is still unknown. Monoclonal antibody therapy is also evolving. For example, technology now exists to deliver isolated antibody light chains that might have a wide biodistribution in the eye after topical application. ${ }^{130} \mathrm{It}$ is also possible to develop monoclonal antibodies that recognize two or more targets and thus might be more efficacious than an inhibitor of a single target. DARPins are ankyrin repeat proteins that resemble antibodies in that they can have 
antigen specificity. ${ }^{131}$ They are being studied in the treatment of retinal diseases. ${ }^{132}$

A major unanswered question is whether biologic therapies will be effective if delivered locally to the eye. The fluocinolone implant has demonstrated that local corticosteroid therapy in the eye can be extremely effective but it is also highly toxic. The development of new slow-release materials will undoubtedly further the attractiveness of local therapy. Intravitreal therapy has the potential to achieve efficacy while minimizing or eliminating systemic toxicity. Infliximab has been injected directly into the eye. While it reportedly has benefited in the treatment of BD-related uveitis, ${ }^{133}$ others have cautioned its use and warned about local toxicity. ${ }^{134}$ We need to learn a great deal more about the risk-benefit ratio of the local delivery of cytokines in the eye.

\section{Conclusion}

Biologics are potent medications that may benefit some, but not all, patients with noninfectious uveitis. They are very useful when conventional immunosuppressive therapy has failed or has been poorly tolerated, or to treat concomitant ophthalmic and systemic inflammation that might benefit from these medications, such as those with RA, JIA, AS, $\mathrm{BD}$, and IBD. It has been shown that with proper monitoring, biologic therapy can significantly improve QOL in patients with uveitis, particularly those with concurrent systemic symptoms.

Given their cost as well as the limited long-term safety data, we do not routinely recommend biologics as first-line therapy for noninfectious uveitis in most patients. However, exceptional considerations for earlier use may be made for those with vision-threatening conditions, such as severe BDrelated panuveitis with retinal vasculitis, especially when corticosteroid therapy is contraindicated and the onset of action from conventional immunosuppressive agents may lag behind.

Evidence suggests that etanercept may not be as effective for uveitis as infliximab and adalimumab. Some biologics are also believed to cause paradoxical inflammatory responses. Daclizumab and efalizumab may be effective for some uveitis subtypes, but their use became historical after removal from the US market. Other agents, such as golimumab, abatacept, canakinumab, gevokizumab, tocilizumab, and alemtuzumab, may have great future promise for the treatment of noninfectious uveitis.

Due to limited data from randomized clinical trials on biologic agents for uveitis, many studies are currently underway. Yet, a journey to discover the ideal medication that is universally and rapidly effective, well tolerated, affordable, and with durable efficacy is to be continued.

\section{Disclosure}

Sirichai Pasadhika has no conflicts of interest to disclose. James Rosenbaum has served as a consultant to Abbott, Amgen, Allergan, Elan, Genentech, Lux Biosciences, Novartis, Santen, Sanofi, Teva, UCB, and Xoma. He has received clinical trial support from Bristol Myers, Genentech, Lux Biosciences, Xoma, Eyegate, and Abbott. He has received research support from Therakine.

\section{References}

1. Jabs DA, Nussenblatt RB, Rosenbaum JT. Standardization of uveitis nomenclature for reporting clinical data. Results of the First International Workshop. Am J Ophthalmol. 2005;140(3):509-516.

2. Wakefield D, Chang JH. Epidemiology of uveitis. Int Ophthalmol Clin. 2005;45(2):1-13.

3. Jabs DA, Rosenbaum JT, Foster CS, et al. Guidelines for the use of immunosuppressive drugs in patients with ocular inflammatory disorders: recommendations of an expert panel. Am J Ophthalmol. 2000;130(4):492-513.

4. Pasadhika S, Kempen JH, Newcomb CW, et al. Azathioprine for ocular inflammatory diseases. Am J Ophthalmol. 2009;148(4):500-509. e2.

5. Gangaputra S, Newcomb CW, Liesegang TL, et al. Methotrexate for ocular inflammatory diseases. Ophthalmology. 2009;116(11): 2188-2198. e1.

6. Pujari SS, Kempen JH, Newcomb CW, et al. Cyclophosphamide for ocular inflammatory diseases. Ophthalmology. 2010;117(2): 356-365.

7. Kacmaz RO, Kempen JH, Newcomb C, et al. Cyclosporine for ocular inflammatory diseases. Ophthalmology. 2010;117(3):576-584.

8. Daniel E, Thorne JE, Newcomb CW, et al. Mycophenolate mofetil for ocular inflammation. Am J Ophthalmol. 2010;149(3):423-432. e1-e2.

9. Sfikakis PP, Theodossiadis PG, Katsiari CG, Kaklamanis P, Markomichelakis NN. Effect of infliximab on sight-threatening panuveitis in Behcet's disease. Lancet. 2001;358(9278):295-296.

10. Ohno S, Nakamura S, Hori S, et al. Efficacy, safety, and pharmacokinetics of multiple administration of infliximab in Behcet's disease with refractory uveoretinitis. J Rheumatol. 2004;31(7):1362-1368.

11. Suhler EB, Smith JR, Wertheim MS, et al. A prospective trial of infliximab therapy for refractory uveitis: preliminary safety and efficacy outcomes. Arch Ophthalmol. 2005;123(7):903-912.

12. Sfikakis PP, Kaklamanis PH, Elezoglou A, et al. Infliximab for recurrent, sight-threatening ocular inflammation in Adamantiades-Behcet disease. Ann Intern Med. 2004;140(5):404-406.

13. Markomichelakis N, Delicha E, Masselos S, et al. A single infliximab infusion vs corticosteroids for acute panuveitis attacks in Behcet's disease: a comparative 4-week study. Rheumatology (Oxford). 2011;50(3): 593-597.

14. Tabbara KF, Al-Hemidan AI. Infliximab effects compared to conventional therapy in the management of retinal vasculitis in Behcet disease. Am J Ophthalmol. 2008;146(6):845-850. e1.

15. Kahn P, Weiss M, Imundo LF, Levy DM. Favorable response to high-dose infliximab for refractory childhood uveitis. Ophthalmology. 2006;113(5):860-864. e2.

16. Rajaraman RT, Kimura Y, Li S, Haines K, Chu DS. Retrospective case review of pediatric patients with uveitis treated with infliximab. Ophthalmology. 2006;113(2):308-314.

17. Richards JC, Tay-Kearney ML, Murray K, Manners P. Infliximab for juvenile idiopathic arthritis-associated uveitis. Clin Experiment Ophthalmol. 2005;33(5):461-468. 
18. Tynjala P, Lindahl P, Honkanen V, Lahdenne P, Kotaniemi K. Infliximab and etanercept in the treatment of chronic uveitis associated with refractory juvenile idiopathic arthritis. Ann Rheum Dis. 2007;66(4): 548-550.

19. Pasadhika S, Suhler EB, Cunningham ET. Use of biologic agents in the treatment of uveitis. Review of Ophthalmology: Retinal Insider. 2010:46-52.

20. Baughman RP, Bradley DA, Lower EE. Infliximab in chronic ocular inflammation. Int J Clin Pharmacol Ther. 2005;43(1):7-11.

21. Pritchard C, Nadarajah K. Tumour necrosis factor alpha inhibitor treatment for sarcoidosis refractory to conventional treatments: a report of five patients. Ann Rheum Dis. 2004;63(3):318-320.

22. Doty JD, Mazur JE, Judson MA. Treatment of sarcoidosis with infliximab. Chest. 2005;127(3):1064-1071.

23. Benitez-del-Castillo JM, Martinez-de-la-Casa JM, Pato-Cour E, et al. Long-term treatment of refractory posterior uveitis with anti-TNFalpha (infliximab). Eye (Lond). 2005;19(8):841-845.

24. Fries W, Giofre MR, Catanoso M, Lo Gullo R. Treatment of acute uveitis associated with Crohn's disease and sacroileitis with infliximab. Am J Gastroenterol. 2002;97(2):499-500.

25. Rispo A, Scarpa R, Di Girolamo E, et al. Infliximab in the treatment of extra-intestinal manifestations of Crohn's disease. Scand J Rheumatol. 2005;34(5):387-391.

26. Ally MR, Veerappan GR, Koff JM. Treatment of recurrent Crohn's uveitis with infliximab. Am J Gastroenterol. 2008;103(8):2150-2151.

27. Bodaghi B, Bui Quoc E, Wechsler B, et al. Therapeutic use of infliximab in sight threatening uveitis: retrospective analysis of efficacy, safety, and limiting factors. Ann Rheum Dis. 2005;64(6):962-964.

28. Jolly M, Curran JJ. Infliximab-responsive uveitis and vasculitis in a patient with Takayasu arteritis. J Clin Rheumatol. 2005;11(4):213-215.

29. Artornsombudh P, Gevorgyan O, Payal A, Siddique SS, Foster CS. Infliximab treatment of patients with birdshot retinochoroidopathy. Ophthalmology. 2013;120(3):588-592.

30. Markomichelakis NN, Theodossiadis PG, Pantelia E, et al. Infliximab for chronic cystoid macular edema associated with uveitis. Am J Ophthalmol. 2004;138(4):648-650.

31. El-Shabrawi Y, Hermann J. Anti-tumor necrosis factor-alpha therapy with infliximab as an alternative to corticosteroids in the treatment of human leukocyte antigen B27-associated acute anterior uveitis Ophthalmology. 2002;109(12):2342-2346.

32. Kruithof E, Kestelyn P, Elewaut C, et al. Successful use of infliximab in a patient with treatment resistant spondyloarthropathy related uveitis. Ann Rheum Dis. 2002;61(5):470.

33. Gupta SR, Phan IT, Suhler EB. Successful treatment of refractory sympathetic ophthalmia in a child with infliximab. Arch Ophthalmol. 2011;129(2):250-252.

34. Adan A, Sanmarti R, Bures A, Casaroli-Marano RP. Successful treatment with infliximab in a patient with diffuse subretinal fibrosis syndrome. Am J Ophthalmol. 2007;143(3):533-534.

35. Lindstedt EW, Baarsma GS, Kuijpers RW, van Hagen PM. Anti-TNF-alpha therapy for sight threatening uveitis. Br JOphthalmol. 2005;89(5):533-536

36. Suhler EB, Smith JR, Giles TR, et al. Infliximab therapy for refractory uveitis: 2-year results of a prospective trial. Arch Ophthalmol. 2009;127(6):819-822.

37. Clementine RR, Lyman J, Zakem J, et al. Tumor necrosis factoralpha antagonist-induced sarcoidosis. J Clin Rheumatol. 2010;16(6): 274-279.

38. Olivier A, Gilson B, Lafontaine S, Pautot JX, Bindi P. [Pulmonary and renal involvement in a TNF $\alpha$ antagonist drug-induced sarcoidosis]. Rev Med Interne. 2012;33(5):e25-e27. French.

39. Izzi S, Francesconi F, Visca P, et al. Pulmonary sarcoidosis in a patient with psoriatic arthritis during infliximab therapy. Dermatol Online J. 2010;16(5):16.

40. Daien CI, Monnier A, Claudepierre P, et al. Sarcoid-like granulomatosis in patients treated with tumor necrosis factor blockers: 10 cases. Rheumatology (Oxford). 2009;48(8):883-886.
41. Dhaille F, Viseux V, Caudron A, et al. Cutaneous sarcoidosis occurring during anti-TNF-alpha treatment: report of two cases. Dermatology. 2010;220(3):234-237.

42. Takahashi H, Kaneta K, Honma M, et al. Sarcoidosis during infliximab therapy for Crohn's disease. J Dermatol. 2010;37(5):471-474.

43. Metyas SK, Tadros RM, Arkfeld DG. Adalimumab-induced noncaseating granuloma in the bone marrow of a patient being treated for rheumatoid arthritis. Rheumatol Int. 2009;29(4):437-439.

44. Javot L, Tala S, Scala-Bertola J, et al. [Sarcoïdosis and anti-TNF: a paradoxical class effect? Analysis of the French Pharmacovigilance system database and literature review]. Therapie. 2011;66(2):149-154. French.

45. Cunningham ET Jr, Pasadhika S, Suhler EB, Zierhut M. Drug-induced inflammation in patients on TNF $\alpha$ inhibitors. Ocul Immunol Inflamm. 2012;20(1):2-5.

46. Cordero-Coma M, Benito MF, Hernandez AM, Antolin SC, Ruiz JM. Serpiginous choroiditis. Ophthalmology. 2008;115(9):1633, 1633. e1-e2.

47. Seve P, Mennesson E, Grange JD, Broussolle C, Kodjikian L. Infliximab in serpiginous choroiditis. Acta Ophthalmol. 2010;88(8):e342-e343.

48. Mackensen F, Becker MD, Wiehler U, et al. QuantiFERON TB-Gold a new test strengthening long-suspected tuberculous involvement in serpiginous-like choroiditis. Am J Ophthalmol. 2008;146(5): 761-766.

49. Pasadhika S, Suhler EB, Cunningham ET. Biologic therapy for posterior uveitis and panuveitis. Retina Today. 2012:74-79.

50. Vazquez-Cobian LB, Flynn T, Lehman TJ. Adalimumab therapy for childhood uveitis. J Pediatr. 2006;149(4):572-575.

51. Biester S, Deuter C, Michels H, et al. Adalimumab in the therapy of uveitis in childhood. Br J Ophthalmol. 2007;91(3):319-324.

52. Simonini G, Taddio A, Cattalini M, et al. Superior efficacy of Adalimumab in treating childhood refractory chronic uveitis when used as first biologic modifier drug: Adalimumab as starting anti-TNF-alpha therapy in childhood chronic uveitis. Pediatr Rheumatol Online J. 2013;11(1):16.

53. Tynjala P, Kotaniemi K, Lindahl P, et al. Adalimumab in juvenile idiopathic arthritis-associated chronic anterior uveitis. Rheumatology (Oxford). 2008;47(3):339-344.

54. Mushtaq B, Saeed T, Situnayake RD, Murray PI. Adalimumab for sight-threatening uveitis in Behcet's disease. Eye (Lond). 2007;21(6): 824-825.

55. Bawazeer A, Raffa LH, Nizamuddin SH. Clinical experience with adalimumab in the treatment of ocular Behcet disease. Ocul Immunol Inflamm. 2010;18(3):226-232.

56. Diaz-Llopis M, Garcia-Delpech S, Salom D, et al. Adalimumab therapy for refractory uveitis: a pilot study. J Ocul Pharmacol Ther. 2008;24(3):351-361.

57. Suhler EB, Lowder CY, Goldstein DA, et al. Adalimumab therapy for refractory uveitis: results of a multicentre, open-label, prospective trial. Br J Ophthalmol. 2013;97(4):481-486.

58. Diaz-Llopis M, Salom D, Garcia-de-Vicuna C, et al. Treatment of refractory uveitis with adalimumab: a prospective multicenter study of 131 patients. Ophthalmology. 2012;119(8):1575-1581.

59. Rudwaleit M, Rodevand E, Holck P, et al. Adalimumab effectively reduces the rate of anterior uveitis flares in patients with active ankylosing spondylitis: results of a prospective open-label study. Ann Rheum Dis. 2009;68(5):696-701.

60. Reiff A, Takei S, Sadeghi S, et al. Etanercept therapy in children with treatment-resistant uveitis. Arthritis Rheum. 2001;44(6): 1411-1415.

61. Quartier P, Taupin P, Bourdeaut F, et al. Efficacy of etanercept for the treatment of juvenile idiopathic arthritis according to the onset type. Arthritis Rheum. 2003;48(4):1093-1101.

62. Smith JA, Thompson DJ, Whitcup SM, et al. A randomized, placebocontrolled, double-masked clinical trial of etanercept for the treatment of uveitis associated with juvenile idiopathic arthritis. Arthritis Rheum. 2005;53(1):18-23. 
63. Foster CS, Tufail F, Waheed NK, et al. Efficacy of etanercept in preventing relapse of uveitis controlled by methotrexate. Arch Ophthalmol. 2003;121(4):437-440.

64. Galor A, Perez VL, Hammel JP, Lowder CY. Differential effectiveness of etanercept and infliximab in the treatment of ocular inflammation. Ophthalmology. 2006;113(12):2317-2323.

65. Taban M, Dupps WJ, Mandell B, Perez VL. Etanercept (enbrel)associated inflammatory eye disease: case report and review of the literature. Ocul Immunol Inflamm. 2006;14(3):145-150.

66. Wang F, Wang NS. Etanercept therapy-associated acute uveitis: a case report and literature review. Clin Exp Rheumatol. 2009;27(5):838-839.

67. Lim LL, Fraunfelder FW, Rosenbaum JT. Do tumor necrosis factor inhibitors cause uveitis? A registry-based study. Arthritis Rheum. 2007;56(10):3248-3252.

68. Cordero-Coma M, Salom D, Diaz-Llopis M, Lopez-Prats MJ, Calleja S. Golimumab for uveitis. Ophthalmology. 2011;118(9):1892. e3-e4.

69. William M, Faez S, Papaliodis GN, Lobo AM. Golimumab for the treatment of refractory juvenile idiopathic arthritis-associated uveitis. J Ophthalmic Inflamm Infect. 2012;2(4):231-233.

70. Miserocchi E, Modorati G, Pontikaki I, Meroni P, Gerloni V. Golimumab treatment for complicated uveitis. Clin Exp Rheumatol. 2013;31(2):320-321.

71. Mesquida M, Victoria Hernandez M, Llorenc V, et al. Behcet diseaseassociated uveitis successfully treated with golimumab. Ocul Immunol Inflamm. 2013;21(2):160-162.

72. Faez S, Lobo AM, Sobrin L, Papaliodis GN. Treatment of seronegative spondyloarthropathy-associated uveitis with golimumab: retrospective case series. Clin Experiment Ophthalmol. Epub September 11, 2013.

73. Tlucek PS, Stone DU. Certolizumab pegol therapy for rheumatoid arthritis-associated scleritis. Cornea. 2012;31(1):90-91.

74. Nussenblatt RB, Fortin E, Schiffman R, et al. Treatment of noninfectious intermediate and posterior uveitis with the humanized anti-Tac mAb: a Phase I/II clinical trial. Proc Natl Acad Sci U SA. 1999;96(13): 7462-7466.

75. Nussenblatt RB, Thompson DJ, Li Z, et al. Humanized anti-interleukin-2 (IL-2) receptor alpha therapy: long-term results in uveitis patients and preliminary safety and activity data for establishing parameters for subcutaneous administration. J Autoimmun. 2003;21(3):283-293.

76. Nussenblatt RB, Peterson JS, Foster CS, et al. Initial evaluation of subcutaneous daclizumab treatments for noninfectious uveitis: a multicenter noncomparative interventional case series. Ophthalmology. 2005;112(5):764-770.

77. Sobrin L, Huang JJ, Christen W, et al. Daclizumab for treatment of birdshot chorioretinopathy. Arch Ophthalmol. 2008;126(2):186-191.

78. Yeh S, Wroblewski K, Buggage R, et al. High-dose humanized antiIL-2 receptor alpha antibody (daclizumab) for the treatment of active, non-infectious uveitis. J Autoimmun. 2008;31(2):91-97.

79. Sen HN, Levy-Clarke G, Faia LJ, et al. High-dose daclizumab for the treatment of juvenile idiopathic arthritis-associated active anterior uveitis. Am J Ophthalmol. 2009;148(5):696-703. e691.

80. Buggage RR, Levy-Clarke G, Sen HN, et al. A double-masked, randomized study to investigate the safety and efficacy of daclizumab to treat the ocular complications related to Behcet's disease. Ocul Immunol Inflamm. 2007;15(2):63-70.

81. Kurz PA, Suhler EB, Choi D, Rosenbaum JT. Rituximab for treatment of ocular inflammatory disease: a series of four cases. Br J Ophthalmol. 2009;93(4):546-548.

82. Onal S, Kazokoglu H, Koc A, Yavuz S. Rituximab for remission induction in a patient with relapsing necrotizing scleritis associated with limited Wegener's granulomatosis. Ocul Immunol Inflamm. 2008;16(5):230-232.

83. Iaccheri B, Androudi S, Bocci EB, et al. Rituximab treatment for persistent scleritis associated with rheumatoid arthritis. Ocul Immunol Inflamm. 2010;18(3):223-225.

84. Sadreddini S, Noshad H, Molaeefard M, Noshad R. Treatment of retinal vasculitis in Behcet's disease with rituximab. Mod Rheumatol. 2008;18(3):306-308.
85. Davatchi F, Shams H, Rezaipoor M, et al. Rituximab in intractable ocular lesions of Behcet's disease; randomized single-blind control study (pilot study). Int J Rheum Dis. 2010;13(3):246-252.

86. Miserocchi E, Pontikaki I, Modorati G, et al. Rituximab for uveitis. Ophthalmology. 2011;118(1):223-224.

87. Heiligenhaus A, Miserocchi E, Heinz C, Gerloni V, Kotaniemi K. Treatment of severe uveitis associated with juvenile idiopathic arthritis with anti-CD20 monoclonal antibody (rituximab). Rheumatology (Oxford). 2011;50(8):1390-1394.

88. Tomkins-Netzer O, Taylor SR, Lightman S. Can rituximab induce long-term disease remission in patients with intra-ocular non-infectious inflammation? Ophthalmologica. 2013;230(3):109-115.

89. Nicholson L, Sobrin L. Anterior uveitis secondary to type II essential cryoglobulinemia. J Ophthalmic Inflamm Infect. 2013;3(1):56.

90. Angeles-Han S, Flynn T, Lehman T. Abatacept for refractory juvenile idiopathic arthritis-associated uveitis- a case report. $J$ Rheumatol. 2008;35(9):1897-1898.

91. Zulian F, Balzarin M, Falcini F, et al. Abatacept for severe anti-tumor necrosis factor alpha refractory juvenile idiopathic arthritis-related uveitis. Arthritis Care Res (Hoboken). 2010;62(6):821-825.

92. Elhai M, Deslandre CJ, Kahan A. Abatacept for refractory juvenile idiopathic arthritis-associated uveitis: two new cases. Comment on the article by Zulian et al. Arthritis Care Res (Hoboken). 2011;63(2): 307-308; author reply 308.

93. Kenawy N, Cleary G, Mewar D, et al. Abatacept: a potential therapy in refractory cases of juvenile idiopathic arthritis-associated uveitis. Graefes Arch Clin Exp Ophthalmol. 2011;249(2):297-300.

94. Suhler EB, Giles TR, Hanel SA, et al. A phase I/II dose-ranging, randomized clinical trial of abatacept (Orencia) in the treatment of refractory non-infectious uveitis: preliminary results. Proceedings of the Association for Research in Vision and Ophthalmology Annual Meeting. May 5-9, 2013; Washington, USA.

95. Birnbaum F, Jehle T, Schwartzkopff J, et al. [Basiliximab following penetrating risk-keratoplasty - a prospective randomized pilot study]. Klin Monbl Augenheilkd. 2008;225(1):62-65. German.

96. Lim WK, Fujimoto C, Ursea R, et al. Suppression of immune-mediated ocular inflammation in mice by interleukin 1 receptor antagonist administration. Arch Ophthalmol. 2005;123(7):957-963.

97. Teoh SC, Sharma S, Hogan A, et al. Tailoring biological treatment: anakinra treatment of posterior uveitis associated with the CINCA syndrome. Br J Ophthalmol. 2007;91(2):263-264.

98. Ugurlu S, Ucar D, Seyahi E, Hatemi G, Yurdakul S. Canakinumab in a patient with juvenile Behcet's syndrome with refractory eye disease. Ann Rheum Dis. 2012;71(9):1589-1591.

99. Simonini G, Xu Z, Caputo R, et al. Clinical and transcriptional response to the long-acting interleukin-1 blocker canakinumab in Blau syndrome-related uveitis. Arthritis Rheum. 2013;65(2):513-518.

100. Gul A, Tugal-Tutkun I, Dinarello CA, et al. Interleukin-1betaregulating antibody XOMA 052 (gevokizumab) in the treatment of acute exacerbations of resistant uveitis of Behcet's disease: an openlabel pilot study. Ann Rheum Dis. 2012;71(4):563-566.

101. Tappeiner C, Heinz C, Ganser G, Heiligenhaus A. Is tocilizumab an effective option for treatment of refractory uveitis associated with juvenile idiopathic arthritis? J Rheumatol. 2012;39(6):1294-1295.

102. Hirano T, Ohguro N, Hohki S, et al. A case of Behcet's disease treated with a humanized anti-interleukin-6 receptor antibody, tocilizumab. Mod Rheumatol. 2012;22(2):298-302.

103. Adan A, Mesquida M, Llorenc V, Modesto C. Tocilizumab for retinal vasoproliferative tumor secondary to juvenile idiopathic arthritisassociated uveitis: a case report. Graefes Arch Clin Exp Ophthalmol. Epub September 24, 2013.

104. Oshitari T, Kajita F, Tobe A, et al. Refractory uveitis in patient with castleman disease successfully treated with tocilizumab. Case Rep Ophthalmol Med. 2012;2012:968180.

105. Adan A, Mesquida M, Llorenc V, et al. Tocilizumab treatment for refractory uveitis-related cystoid macular edema. Graefes Arch Clin Exp Ophthalmol. 2013;251(11):2627-2632. 
106. Wendling D, Dernis E, Prati C, Frisch E, Delbosc B. Onset of inflammatory eye disease under tocilizumab treatment for rheumatologic conditions: a paradoxical effect? J Rheumatol. 2011;38(10):2284.

107. Isaacs JD, Watts RA, Hazleman BL, et al. Humanised monoclonal antibody therapy for rheumatoid arthritis. Lancet. 1992;340(8822): 748-752.

108. Coles AJ, Twyman CL, Arnold DL, et al. Alemtuzumab for patients with relapsing multiple sclerosis after disease-modifying therapy: a randomised controlled phase 3 trial. Lancet. 2012;380(9856): 1829-1839.

109. Isaacs JD, Hale G, Waldmann $\mathrm{H}$, et al. Monoclonal antibody therapy of chronic intraocular inflammation using Campath-1H. Br J Ophthalmol. 1995;79(11):1054-1055.

110. Dick AD, Meyer P, James T, et al. Campath-1H therapy in refractory ocular inflammatory disease. Br J Ophthalmol. 2000;84(1):107-109.

111. Lockwood CM, Hale G, Waldman H, Jayne DR. Remission induction in Behcet's disease following lymphocyte depletion by the anti-CD52 antibody CAMPATH 1-H. Rheumatology (Oxford). 2003;42(12): 1539-1544

112. Wang J, Ibrahim M, Turkcuoglu P, et al. Intercellular adhesion molecule inhibitors as potential therapy for refractory uveitic macular edema. Ocul Immunol Inflamm. 2010;18(5):395-398.

113. Faia LJ, Sen HN, Li Z, et al. Treatment of inflammatory macular edema with humanized anti-CD11a antibody therapy. Invest Ophthalmol Vis Sci. 2011;52(9):6919-6924.

114. Talamonti M, Teoli M, Botti E, et al. Patients with moderate to severe plaque psoriasis: one year after the European Medicines Agency recommendation of efalizumab suspension. Dermatology. 2011;222(3): $250-255$.

115. Gueudry J, Wechsler B, Terrada C, et al. Long-term efficacy and safety of low-dose interferon alpha2a therapy in severe uveitis associated with Behcet disease. Am J Ophthalmol. 2008;146(6):837-844. e831.

116. Becker MD, Heiligenhaus A, Hudde T, et al. Interferon as a treatment for uveitis associated with multiple sclerosis. Br J Ophthalmol 2005;89(10):1254-1257.

117. Kötter I, Gunaydin I, Zierhut M, Stubiger N. The use of interferon alpha in Behçet disease: review of the literature. Semin Arthritis Rheum. 2004;33(5):320-335.

118. Deuter CM, Koetter I, Guenaydin I, Stuebiger N, Zierhut M. Interferon alfa-2a: a new treatment option for long lasting refractory cystoid macular edema in uveitis? A pilot study. Retina. 2006;26(7): 786-791.

119. Deuter C, Stubiger N, Zierhut M. Interferon-alpha therapy in noninfectious uveitis. Dev Ophthalmol. 2012;51:90-97.
120. Doycheva D, Deuter C, Stuebiger N, Zierhut M. Interferon-alphaassociated presumed ocular sarcoidosis. Graefes Arch Clin Exp Ophthalmol. 2009;247(5):675-680.

121. Alazemi S, Campos MA. Interferon-induced sarcoidosis. Int J Clin Pract. 2006;60(2):201-211.

122. Nussenblatt RB. The natural history of uveitis. Int Ophthalmol. 1990;14(5-6):303-308.

123. Rothova A, Suttorp-van Schulten MS, Frits Treffers W, Kijlstra A. Causes and frequency of blindness in patients with intraocular inflammatory disease. Br J Ophthalmol. 1996;80(4):332-336.

124. Schiffman RM, Jacobsen G, Whitcup SM. Visual functioning and general health status in patients with uveitis. Arch Ophthalmol. 2001;119(6):841-849.

125. Maini R, O'Sullivan J, Reddy A, Watson S, Edelsten C. The risk of complications of uveitis in a district hospital cohort. Br J Ophthalmol. 2004;88(4):512-517.

126. Rosenbaum JT, Russell AS, Guenther LC, El-Gabalawy H. The influence of uveitis on patients with immune-mediated inflammatory disease. J Rheumatol Suppl. 2011;88:26-30.

127. Minden K, Niewerth M, Zink A, et al. Long-term outcome of patients with JIA treated with etanercept, results of the biologic register JuMBO. Rheumatology (Oxford). 2012;51(8):1407-1415.

128. Sakai T, Watanabe H, Kuroyanagi K, et al. Health- and vision-related quality of life in patients receiving infliximab therapy for Behcet uveitis. Br J Ophthalmol. 2013;97(3):338-342.

129. Athanasakis K, Petrakis I, Kyriopoulos J. Investigating the value of abatacept in the treatment of rheumatoid arthritis: a systematic review of cost-effectiveness studies. ISRN Rheumatol. 2013;2013:256871.

130. Thiel MA, Wild A, Schmid MK, et al. Penetration of a topically administered anti-tumor necrosis factor alpha antibody fragment into the anterior chamber of the human eye. Ophthalmology. 2013;120(7):1403-1408.

131. Stahl A, Stumpp MT, Schlegel A, et al. Highly potent VEGF-Aantagonistic DARPins as anti-angiogenic agents for topical and intravitreal applications. Angiogenesis. 2013;16(1):101-111.

132. Campochiaro PA, Channa R, Berger BB, et al. Treatment of diabetic macular edema with a designed ankyrin repeat protein that binds vascular endothelial growth factor: a phase I/II study. Am J Ophthalmol. 2013;155(4):697-704, 704. e1-e2.

133. Markomichelakis N, Delicha E, Masselos S, Sfikakis PP. Intravitreal infliximab for sight-threatening relapsing uveitis in Behcet disease: a pilot study in 15 patients. Am J Ophthalmol. 2012;154(3): 534-541. e531.

134. Giganti M, Beer PM, Lemanski N, et al. Adverse events after intravitreal infliximab (Remicade). Retina. 2010;30(1):71-80.
Biologics: Targets \& Therapy

\section{Publish your work in this journal}

Biologics: Targets \& Therapy is an international, peer-reviewed journal focusing on the patho-physiological rationale for and clinical application of Biologic agents in the management of autoimmune diseases, cancers or other pathologies where a molecular target can be identified This journal is indexed on PubMed Central, CAS, EMBase, Scopus

\section{Dovepress}

and the Elsevier Bibliographic databases. The manuscript management system is completely online and includes a very quick and fair peerreview system, which is all easy to use. Visit http://www.dovepress. com/testimonials.php to read real quotes from published authors. 